\title{
Employment Creation through Credit: A Glimpse from Credit Program for Ultra-poor Households in Bangladesh
}

\author{
Md. Abdul Khaleque, Mehadi Hasan, and Farah Muneer
}

\section{ABSTRACT}

\begin{abstract}
This paper examined the impact on employment of a credit plus program designed for ultra-poor households in the Northwest region of Bangladesh. Both descriptive and econometric techniques were used, and four regression models were estimated for each of the dependent variables with linear and log-lin specifications: one is a simple model considering only time effect and program effect, and the others were the extended models which included various characteristics of the households and the regions. The descriptive analysis showed that most of the beneficiary households had shifted from single earning members to multiple earning members. Women had started to contribute to household earnings. The results showed that the participant ultra-poor households had gained around $21.1 \%$ additional employment days due to the program participation opportunities within 2008-2013, with an annual rate of $4.2 \%$ gain. The extra earning days included wageemployment days and self-employment days and the results showed that due to the program, the wage-employment days had increased by $2.6 \%$ annually and the self-employment days increased by $6.6 \%$ annually holding the effects of other explanatory variables constant. The working days of nonparticipants had increased but at a lower rate than that of the program participant households. The results confirmed that the credit program for ultra-poor households had a significantly positive effect on the creation of employment days and employment opportunities.
\end{abstract}

Submitted : November 11,2021

Published : December 07, 2021

ISSN: 2507-1076

DOI: $10.24018 /$ ejbmr.2021.6.6.1166

Md. Abdul Khaleque*

Assistant Professor, Department of Development Studies, University of Dhaka, Bangladesh

(e-mail: khaleque@du.ac.bd)

Mehadi Hasan

Manager (Research), Palli Karma-Sahayak Foundation (PKSF), Bangladesh.

(e-mail: saon766@gmail.com)

Farah Muneer

National Consultant, UNDP, Bangladesh. (e-mail: muneerfarah@gmail.com)

*Corresponding Author

Keywords: Difference-in-Difference, Microcredit, self-employment, wageemployment.

\section{INTRODUCTION}

Employment is the source of income and therefore, the key determinant of the welfare of an individual. In a simple microeconomic sense, individual faces the trade-off between leisure and work. To attain a certain level of welfare, the individual has to work and has to forego a certain level of leisure. When people want to work and there is no scope of work, they may have to live a miserable life or a poor life. But leading a miserable life is not expected. According to the universal declaration of human rights of the general assembly of the United Nations, Article 25(1) "everyone has a right to a standard of living adequate for the health and well-being of themselves and their family, including food, clothing, housing, medical care, necessary social services and the right to security in the event of unemployment, sickness, disability, widowhood, old age or other lack of livelihood in circumstances beyond control." In the human rights system state and organized society has to create the conditions and opportunities for its citizens - the right to work, access to food, access to education, access to shelter, and access to health and ensure human rights for all citizens so that they can overcome the state of poverty. Poverty can be viewed narrowly as the deprivation of basic human needs (Yunus, 1987) or as entitlement failure.

Opportunity to work may be created broadly in three ways: formal salaried job, wage-employment, and selfemployment. The scope of formal salaried employment is limited and finding wage employment is considered as a fortune for some of the people, for example, women, in many countries where the tradition of female employment is limited. Yunus (1987) mentioned that wage employment is not a suitable road in reducing poverty. Poverty alleviation must contain the opportunity of asset creation so that at any cycle of the economy, the individual can cope with idiosyncratic or covariate shocks. The potentiality of ameliorating the asset portfolio is much higher among the self-employment group than the wage employment group. The average return to self-employment is higher than the wage rate (Rushidan \& Khandker, 1996).

Self-employment is getting a lot of attention recently. Measures to promote self-employment such as labor laws, support for large businesses and local communities, secured loans, etc., are taken up by policymakers. Occupational choice or household's dependence on income sources plays an essential role of livelihood strategy of the households. In a poor or a developing country, the households are primarily dependent on wage, with limited opportunities of selfemployed income, or, in some cases, both types of incomes. The choice is determined by the set of household characteristics like the demographic composition and the capital endowment of the households. Literature showed that wage-dependent households are more susceptible to poverty or any economic shock than non-wage-dependent households. The literature on the credit market showed that capital constraints inhibit the innate capacity of potential 
entrepreneurs. This limitation is very severe for the poorest people. But the access to capital for these people, often, opens up a world of opportunities for new employment opportunities and propels the escape from extreme poverty. The escape from poverty is very much linked with the opportunities of high yielding economic activities like enterprise.

Three goals are most frequently cited in the World Bank study of micro-and small-business lending (Webster et al., 1996): (i) job creation and income creation through the creation and expansion of small businesses; (ii) increase productivity and income for vulnerable groups, especially women and the poor, and (iii) reduce rural households' dependence on crop by diversifying income-generating activities. The access and availability of credit opens such opportunities. While mature microfinance has largely succeeded in providing credit and non-credit services to the poor or middle-poor, most of the very poor are still poorly provided. The poorest also demanded microfinance services. Microfinance institutions must provide services that bridge the gap and integrate vulnerable groups into the marketplace. From a functional point of view, it is difficult to promote selfemployment only in the very poor, who have to combine wage and self-employment in the short term due to high daily wage dependence.

Access to finance is one of the important elements to create or promote self-employment. From the outset of development, loans play an important role in financing the project. Loans for financing are sometimes essential because of the low amount of equity. Some households may have access to official credit due to the availability of a mortgage. Without a mortgage, many potential poor entrepreneurs are excluded from credit services. The advent of microfinance has largely solved this problem and has played an important role in promoting self-employment in traditional activities. The expansion of microfinance in Bangladesh is associated with the expectation that it can help create self-employment that can ultimately solve both unemployment and poverty (Halder, 2003). In Bangladesh, BRAC promotes selfemployment through (microfinance and technical assistance) and human development (non-formal education and health care) (Hulme \& Moore, 2007). Grameen Bank's goal is to reduce poverty and empower women by encouraging new business development or diversifying existing businesses.

Credit, an important means of lubricating trade, commerce, and industry, plays a powerful economic, social and political role in the economy. Credit creates an entitlement to resources. Sometimes, credit is called a powerful economic weapon and so this has to be managed effectively and efficiently. This is because, on one hand, a better-managed credit can equip a dispossessed individual to give a fight against economic odds around him or her, on the other hand, poorly managed credit can even make the individual more vulnerable to economic odds. One fundamental question in credit literature is 'does credit create employment opportunity?' Mondragon (2018) estimated the effect of the contraction in the supply of credit to households on the level of employment during the Great Recession and found that the contraction of the supply of credit to households declined employment during the Great Recession. The elasticity between the size of credit to household and the level of employment was estimated at 0.3 suggesting the incremental credit created employment opportunity. Credit market disruptions, however, may limit the effects. Chodorow-Reich (2014) investigated the effect of bank lending frictions on employment outcomes. He showed that bankruptcy reduced one-half of the employment. Moyi (2013) tried to reveal the link between credit constraint and employment opportunity and concluded with an insignificant direct relationship between these two, but relationships found significant when credit constraint is associated with access to workspace, access to technology, and business formalities. The relationship between financial development and employment is evident in the literature. For example, Pagano and Pica (2012) modeled and predicted that financial development increased employment and/or labor productivity and wages and Boustanifar (2014) found that banking reform increased employment growth.

The literature on finance and financial development does reveal that finance creates employment opportunities and employment growth. But the question remains on what kind of finance can bring this auspicious result and in the era of microcredit question prevails like does microcredit create employment and if so it does create self-employment! Some studies examined these kinds of questions. Rushidan and Khandker (1996) examined that the microcredit program was successful in expanding the opportunities of self-employment and Khandker (1996) found that such credit opportunities increased the rural non-farm activities through relaxing credit constraints. Pitt (2000) found that the group-based microcredit program opened up the scope of production credit for non-agricultural activities for the landless and asset-less rural households which increased self-employment labor hours and reduced wage-employment labor hours through increasing sharecropping and land leasing.

This paper aims at investigating the impact of microcreditplus program on employment creation. The specific research question is whether microcredit creates employment or not and if yes, what kinds of employment - wage-employment or self-employment or their mix. In the first case, we attempt to reveal the fundamental relationship between employment and microcredit among poor households, and in the second case; we explore the nature of employment: wage-employment or self-employment. Albeit the limited literature on these questions suggests a positive relationship between the supply of microcredit and the level of employment with the conclusion of the increase in the employment among the borrowing households, but we hypothesize that such relationship is mere or insignificant among the extremely poor households. This is because while the evidence of the effectiveness of the credit depends on the stability of the firm/farms and extremely poor people are very much vulnerable to shocks.

\section{LITERATURE REVIEW}

Household Income and Expenditure Survey of BBS and Labor Force Survey are two important sources of understanding the distribution of employment status of individuals. The HIES surveys $(2005,2010)$ have shown that near around half of the active population were engaged with agriculture, animal husbandry, forestry, and fisheries; around 
9-12\% in sales activities; around 5-7\% in service; and less than $2 \%$ in administrative \& managerial works. According to LFS (2010), around $47 \%$ of the household income came from self-employment activities: $31 \%$ from self-employment in agriculture and $16 \%$ from self-employment in nonagriculture; $40 \%$ income came from wage-employment: $14 \%$ from non-agricultural wage income and $26 \%$ from agricultural wage income; and only $9 \%$ income came from service. The report of HIES (2010) showed that the share of agriculture income was around $29.7 \%$ whereas the share of professional wage and salary was around $29.6 \%$. The share of business and commerce in household income was approximately $15 \%$ and around $17.3 \%$ of income came in the form of gifts and remittance.

The occupational distribution and income share of the households from various sources showed that a limited number of individuals are engaged in business, but a significant amount of income comes from self-employment activities. What determines self-employment? The factors affecting employment include a set of individual-level variables describing the characteristics of the individuals, household-level variables describing the social capital or household capital, regional variables describing the location and economic activity in that area, and overall economic condition describing the macroeconomic effects on the individuals' choice. The individual characteristics include the age, gender, education, and status of business training or working experience while the household level variables include the household composition or household size, landholding, access to electricity, asset, and equipment.

Av (2013) mentioned some micro-environment and macroenvironment factors which helped to form personal determination to start up self-employment and duration of self-employment activities. They also identified factor groups like economic, demographical, political, psychological, social, and others alongside factors like gender, race, marital status, unemployment duration, age, wages, gender gaps in employment sectors, business cycles, microeconomic conditions, etc.

Studies (Aidis, 2003; Wagner \& Sternberg, 2004; Brixiova, 2011; Korpysa, 2011) argued that the choice of selfemployment as a profession is primarily a personal decision. Rees and Shah (1986) found that age and education significantly determine self-employment. Wagner and Sternberg (2004) identified personal factors (gender, age, education, occupational status); micro-environment motivation, demographical factors, personal characteristics, education) and macro-environment (cultural, social, political, financial factors, educational system, infrastructure, and economic infrastructure).

Households are dependent on various economic activities. Several factors influence their livelihood movements. For example, with an increase in the education level of the family members, the probability of moving from low productive activity to highly productive activity. In general, higher education levels move the family members from low-wage agricultural jobs to high-paying economic activities. In a rural setting, the high returns come through self-employment. A hundred plans of the poorest cannot be implemented due to credit constraints. Some poor families need money to make small investments in self-employment opportunities, but lack of access to credit markets due to lack of collateral or information keep their hopes under the dreamy zones. As a result, they cannot become self-sufficient due to lack of funds, or if they start a business, they face financial constraints in developing a business that can generate income which is above the poverty line. At the macro level, the lack of financial capital for micro and small businesses has been a major obstacle for the small private sector. This was true not only in development but also in the transition period of developed countries (Kritikos et al., 2005).

Though microfinance is a very different business, it targets the "micro" businesses which most often involve selfemployment in the informal sector, and women make up a large and growing segment of informal-sector businesses (Armendáriz et al., 2010, p. 216). As Emran et al. (2007) argued in an important rethinking of missing markets, the logic about the lack of credit alternatives can be extended to other missing markets: where women lack adequate access to labor markets, women will value self-employment opportunities all the more-and will have stronger incentives for diligence in repaying loans. Alnaa (2017) using the bivariate probit selection model showed that access to microcredit increased the probability of employment creation by around 46\%. The study of Atiase et al. (2019) also concluded that in Ghana the access to microcredit created employment among medium and small enterprises. Sahu (2021) found that credit size and employability are positively related. Tria et al. (2020) found that the availability of microcredit engendered the opportunity for productive activity and change the structure of employment by sector, gender, and types of employment. The quality of the microcredit scheme significantly positively increased entrepreneurship in Nigeria (Shehu et al., 2021). The study of Habiba and Awan (2020) showed that microcredit and networking with the mediating effect of social capital improved the performance of micro, small and medium enterprises in Pakistan.

Goetz et al. (1996) argued that credit confers a specific set of advantages when targeting low-income women. This is seen as an essential element to increase women's employment in small businesses and should encourage the adoption of innovative technologies to enhance the productivity of women's farm-based income-generating activities. Instead of creating job opportunities for housewives or unemployed adults, if the household devoted themselves to the activities, paddy husking, retail trade, rearing livestock, there is a negative return when it is measured by men's agricultural wages (Hossain, 1984).

Sometimes access to credit encourages small traders to exchange goods or facilitate sellers' activity. Households moved from wage employment to self-employment. However, such changes do not happen overnight and take time. Therefore, in the short term, most of the extreme poor are moving from wage employment activity to selfemployment. In the long run, microfinance programs can help some households find self-employment. Khandker (2001) stated that microfinance programs support the production and consumption of the poor. He believed that preferential terms on loan repayment would limit consumption and helped the unemployed find independent work. Hossain (2002) found that by joining Grameen Bank, about a third of its members 
created new jobs. They created new jobs primarily for female members, of which nearly half reported unproductive activity before joining Grameen Bank. As a result, a third of female members no longer work as housekeepers. It was found that $7 \%$ of male members were unemployed before joining the Grameen Bank loan program.

\section{DEFINING WAGE-EMPLOYMENT AND SELF- EMPLOYMENT}

The source of household income can be used to determine the occupation of the household. A household is said to be a wage employed household if all of their income comes from the wage income, a household is said to be self-employed only if the income comes purely from non-wage activity; if the income is made up from wage and non-wage activities, the households are considered as mixed employed households. To model employment and participation in the ultra-poor program by the households, we used working days devoted to wage employment, self-employment, or both. We have also considered the working days of wage-employed household heads, self-employed workers, working days of men and women, and total working days of household members.

\section{THEORETICAL FRAMEWORK}

To understand the choice of occupation, we are following the model described by Banerjee and Newman (1993). They model the economic development of an agent as a process of the transformation of the institution via the decision of the occupation and the wealth distribution as the occupational structure depends on the distribution of wealth. They keenly focus on financial market imperfection and borrowing constraints in making occupational decisions of the agents.

\section{A. The Model}

Banerjee and Newman (1993) developed the model based on some simplistic assumptions. They assume that the agents have identical preferences. They consider $G_{t}(w)$ as the measure of the population with wealth less than $w$ and $A$ as the cohort size. They postulate that at the beginning of life, agents have initial wealth which is a bequest from their parents. Additionally, they have an endowment of one unit of labor. Agents can work, borrow, and invest only when they become economically active. Agents may apply for a loan in a loan market that is assumed to be imperfect and thereby, lenders have a high preference of limiting borrowing through the requirement of collateral. Therefore, agents will choose an occupation based on their unit labor and the size of capital.

The preference over commodities of the risk-neutral agents is given by the expression $c^{\gamma} b^{1-\gamma}-z$ where $c$ represents the consumption of physical goods, $b$ is the amount the good left as a bequest to his offspring, and $z$ is the amount of labor he supplies. Denoting the income realization by $y$; the utility then takes the form $\delta y-z$ where $\delta=\gamma^{\gamma}(1-\gamma)^{1-\gamma}$.

The economy's single good may be used for consumption or as capital. Agents can invest it in three ways: first, an investment in a safe asset that requires no labor and yields a fixed gross return of $\hat{r}<\frac{1}{1-\gamma}$; second, an investment in a risky project which will require an initial investment of $I$ and one unit of labor and if the project becomes successful, it will yield a random return of $r I$ where $r$ is $r_{0}$ or $r_{1}$ with probabilities $(1-q)$ and $q$ with $0<r_{0}<r_{1}$ and mean $\bar{r}$; and the project may be efficiently operated by a self-employed agent insofar as it produces enough output to cover its labor cost:

$$
I(\bar{r}-\hat{\gamma})-\frac{1}{\delta} \geq \max \left\{0,\left(r_{0}-\hat{\gamma}\right)\right\}
$$

Finally, there is a monitoring technology that permits aggregated production and requires full efforts of the labor and with it, it can perfectly monitor of $\mu>1$ individual. In this case, an entrepreneur can hire $\mu$ workers with a competitive wage of $v$, can have random returns $r^{\prime} I^{\prime}$ where $r^{\prime}$ is $r_{0}^{\prime}$ or $r_{1}^{\prime}$ with probabilities $\left(1-q^{\prime}\right)$ and $q^{\prime}$ with $0<r_{0}^{\prime}<r_{1}^{\prime}$ and mean $\bar{r}$ for $I^{\prime}$ units of capital with the unit labor, and they presume that $I=I^{\prime}$ and $r$ and $r^{\prime}$ mean the same as in second case but $q^{\prime} \neq q$. The production is feasible in this case and is more profitable than self-employment:

$$
\begin{gathered}
\mu\left[I(\bar{r}-\hat{\gamma})-\left(\frac{1}{\delta}\right)\right]-\left(\frac{1}{\delta}\right) \geq \max \{I(\bar{r}-\hat{\gamma})- \\
\left.\left(\frac{1}{\delta}\right), \mu\left[I\left(r_{0}^{\prime}-\hat{\gamma}\right)-\left(\frac{1}{\delta}\right)\right]\right\} .
\end{gathered}
$$

The discussion of Banerjee and Newman (1993) considers four occupational options: (i) subsistence, (ii) working, (iii) self-employment, and (iv) entrepreneurship ${ }^{1}$. They discuss the issues with the market of loans where lenders can freely enter but borrowers might renege on debt. Suppose that the agent has a wealth of $w$ which can be put as collateral to borrow $L$ amount of loan. The payoff of using the loan is $V(L)$. The reneging yields a payoff of $V(L)-\pi F$ where $F$ is non-monetary punishment and a repayment yields $V(L)+$ $w \hat{r}-L \hat{r}$ where $w \hat{r}$ represents the cost of the lost collateral and $L \hat{r}$ represents repayment. The borrower will renege if $w \hat{r}+\pi F<L \hat{r}$ and this information induces the lenders to set the restriction $L \leq w+\pi F / \hat{r}$. The payoffs of the subsistence are $\delta w \hat{r}, \quad$ worker, $\delta(w \hat{r}+v)-1$; $\quad$ selfemployment, $\delta[w \hat{r}+I(\bar{r}-\hat{\gamma})]-1, \quad$ and entrepreneur, $\delta[w \hat{r}+\mu I(\bar{r}-\hat{\gamma})-\mu v]-1$.

McKernan (2002) attempted to measure the total and noncredit effects of microcredit on productivity and selfemployment profit. He considered the following production function.

$$
Y=f\left(L_{f Y}, L_{m Y}, A ; K, N, \epsilon\right)
$$

The production function consists of hired or household labor (female $L_{f Y}$ and male labor $L_{m Y}$ ), the input vector $A$, capital stock $K$, human capital $H$ which measures cognitive ability in the household, and quantity of land $N$. The term $\epsilon$ refers to a stochastic shock having zero mean and constant variance.

\footnotetext{
${ }^{1}$ See Banerjee and Newman (1993) to see how they rule out the other possibilities of occupational options.
} 
The household income is an aggregate income, income of various individuals in the households, and is from various sources like wage income and self-employment profit as mentioned earlier. Therefore, household income is given by:

$$
M=w L+\pi
$$

The household income depends on the household's choice between labor days and leisure decisions. The household utility function is given by:

$$
U=U\left(X, l_{f}, l_{m}\right)
$$

where $X$ represents purchased consumers goods, and $l_{f}$ and $l_{m}$ denote leisure or household time of the female and male labor. The time constraints of the female and male are given by:

$$
L_{f}=L_{f Y}+L_{f w}+l_{f}
$$

and

$$
L_{m}=L_{m Y}+L_{m w}+l_{m}
$$

where $L_{f Y}$ refers labor supply of female workers in producing $Y, L_{f w}$ is the labor supply of female workers in wage employment, and $l_{f}$ is the amount of leisure period of the female workers. The term $L_{m}$ refers to the total available time of male workers in the household of which $L_{m Y}$ is used in producing $Y, L_{m w}$ is allotted for wage employment, and $l_{m}$ is for leisure respectively.

The household maximizes utility subject to three constraints: first, the time constraint, second, the budget constraint, and third, the production technology. The household first decides whether to undertake a selfemployment enterprise and chooses the levels of capital to be used in the enterprise. Households calculate expected profit conditional on optimally choosing inputs given their fixed quantity of land. The household then compares the indirect utility of expected profit from undertaking the activity, $V_{1}$, defined as $V_{1}=V_{1}\left(P_{x}, P_{y}, w, P_{A}, P_{k}, L, H, N\right)$ with indirect expected utility when not undertaking the activity, where $V_{0}=V_{0}\left(P_{x}, w\right)$. The effect of microcredit on selfemployment can be via physical capital or human capital. In this framework, McKernan (2002) drew the implication that microcredit programs increase access to physical and human capital and this access enables the households to undertake or expand self-employment enterprises.

\section{MODEL SPECIFICATION}

Banerjee and Newman (1993) explain the occupational choices based on the opportunity of access to credit in a purely abstract form while McKernan (2002) shows the effect of microcredit on self-employment profit. We have used their techniques to assess the effect of credit and non-credit components of PRIME project on working days where working days consists of wage-employment days and selfemployment days under the assumption that with constant wage or return to self-employment, the income of the household can be estimated.

$$
\begin{aligned}
Y_{i t}^{g}=\alpha+\beta_{t d} Y_{\text {ear }}+ & +\beta_{p d} \text { Participant } \\
& +\beta_{\text {did }}\left(\text { Year }_{2} \times \text { Participant }\right)+\epsilon_{i t}
\end{aligned}
$$

Here $Y_{i t}^{g}$ represents the dependent variable which may be working days during a year for example wage-employment days, self-employment days, or total working days. The term $Y_{i t}^{g}$ may represent the occupational status in wageemployment or self-employment of both and the superscript $g$ indicates gender and the subscript $i$ indicates households and $t$ indicates time. The regression model represents the simple difference-in-difference model and follows the standard assumption of the difference-indifference model. This model is simple as it does not include the other variables like characteristics of the household, household head, and regional characteristics.

The simple model has been extended by the inclusion of a set of explanatory variables. In the first case, we have added the landholding into the model. The inclusion of landholding in the regression model will determine the extent of selfemployment days or the occupational status of the household head or the household. In the second case, we have added some household level explanatory variables and in the third case, we have added some characteristics of the household head along with the district dummies to capture regional effects. The extended models are:

$$
\begin{aligned}
& Y_{i t}^{g}=\alpha+\beta_{t d} \text { Year }_{2}+\beta_{p d} \text { Participant }+\beta_{\text {did }}\left(\text { Year }_{2} \times\right. \\
& \text { Participant })+\beta_{4} \text { Land }_{i t}+\epsilon_{i t}
\end{aligned}
$$

$$
\begin{aligned}
& Y_{i t}^{g}=\alpha+\beta_{t d} \text { Year }_{2}+\beta_{p d} \text { Participant }+\beta_{\text {did }}\left(\text { Year }_{2} \times\right. \\
& \text { Participant })+\beta_{4} \text { Land }_{i t}+\beta_{h} X_{i t}^{h}+\epsilon_{i t}
\end{aligned}
$$

$Y_{i t}^{g}=\alpha+\beta_{t d} Y_{e a r_{2}}+\beta_{p d}$ Participant $+\beta_{\text {did }}\left(\right.$ Year $_{2} \times$ Participant $)+\beta_{4}$ Land $_{i t}+\beta_{h} X_{i t}^{h}+\beta_{h h} X_{i t}^{h h}+$

$\beta_{\text {distdum }}$ District $+\epsilon_{i t}$

In the above models, Land $_{i t}$ measures the level of landholdings by the household; $X_{i t}^{h}$ is the set of householdlevel explanatory variables; $X_{i t}^{h h}$ is the set of characteristics of the household head and District represents the district dummies.

\section{MATERIALS AND METHODS}

In this study, we have used the PKSF-InM survey data of around 3864 households. The households were selected using a multi-stage cluster sampling and the total size of the population was around 480,918 poor households in the greater Rangpur. The households are from five districts of Rangpur division. The survey was carried several rounds and based on those surveys a panel data was constructed. The analysis presented in this paper is based on data collected in two periods: the year 2008, the early stage of PRIME, and the year 2013, the end line of PRIME. In between those two periods, the infiltration of credit and non-credit interventions expanded by PRIME and other microfinance organizations, and the choice of joining in microfinance program by households in those areas expanded. 
TABLE I: STATUS OF HOUSEHOLD’S PARTICIPANT IN CREDIT AND NONCREDIT PROGRAM

\begin{tabular}{cccc}
\hline \hline Status of Participation & \multicolumn{2}{c}{ Year } & \multirow{2}{*}{ Total } \\
\cline { 2 - 3 } & 2008 & 2013 & \\
\hline PRIME Credit-Plus Participant (PCP) & 593 & 810 & 1,403 \\
PRIME Credit only Participant (PCO) & 1,012 & 1,244 & 2,256 \\
Non-PRIME Credit only Participant (NPCO) & 1,384 & 2,189 & 3,573 \\
Non-PRIME Credit-Plus Participant (NPCP) & 209 & 359 & 568 \\
Non-Participant (NP) & 666 & 1,000 & 1,666 \\
Total & 3,864 & 5,602 & 9,466 \\
\hline
\end{tabular}

Source: PRIME Survey Data (2008, 2013).

Note: We have constructed a balanced panel of 3,864 households for the analysis of this study.

By balancing the sample household, we finally reached the sample of 3864 households in both years (Table I).

The households had some distinct characteristics. For example, PRIME households had an average land size of 10.38 decimal in 2008 and that reduced to 8.97 decimal in 2013. In terms of landholding, the households were almost similar. In terms of household size, the non-participant households had lower household sizes compared to the average household size of other categories of the households.

TABLE II: CHARACTERISTICS OF THE HOUSEHOLD AND HOUSEHOLD HEAD BY PARTICIPATION STATUS

\begin{tabular}{ccccccc}
\hline \hline Characteristics & Year & PCP & PCO & NPCO & NPCP & NP \\
\hline Average & 2008 & 10.4 & 9.8 & 10.3 & 9.3 & 10.6 \\
landholding & 2013 & 9.0 & 10.3 & 10.2 & 9.9 & 9.2 \\
\hline Average & 2008 & 4.4 & 4.2 & 4.3 & 4.2 & 3.7 \\
household size & 2013 & 4.3 & 4.1 & 4.2 & 4.2 & 3.5 \\
\hline Electricity & 2008 & 9.6 & 7.5 & 9.5 & 10.1 & 6.3 \\
connection & 2013 & 30.1 & 22.2 & 26.5 & 26.7 & 15.6 \\
\hline Average age of & 2008 & 41.5 & 41.7 & 41.9 & 42.8 & 45.5 \\
household head & 2013 & 44.8 & 45.4 & 46.2 & 46.9 & 49.3 \\
\hline $\begin{array}{c}\text { Average } \\
\text { schooling of }\end{array}$ & 2008 & 1.4 & 1.3 & 1.5 & 1.2 & 1.3 \\
household head & 2013 & 1.5 & 1.2 & 1.4 & 1.6 & 1.1 \\
\hline \hline Source: PRIME SURVEY $(2008,2013)$. & & &
\end{tabular}

Among the PRIME credit participant households, around $30 \%$ had electricity connection in 2013 which was only $9.6 \%$ in 2008 while of the non-participant households, only $15.6 \%$ households had electricity connection in 2013 which was $6.3 \%$ in 2008 . The average age of the household heads was around 45-46 years in 2013 and household heads had a limited size of human capital. The average years of schooling of PRIME credit participant households were 1.53 in 2013 which was 1.05 among the non-participant households (Table II).

\section{FINDINGS}

In 2008, more than half of the households around $65.2 \%$ had single male earning members and around $14.5 \%$ of households had a male and a female earner and only $1 \%$ of households had multiple female earners with a single male earning member. But the scenario changed over time. In $2013,37 \%$ of the households had only a single male earning member and around $34 \%$ of households got earning support from women alongside the single male earning member. Around $15.6 \%$ of households got multiple male earning members where no women contributed to household income (Table III).

TABLE III: DYNAMICS OF EARNERS IN BETWEEN 2008 AND 2013

\begin{tabular}{ccccc}
\hline \hline & & $\begin{array}{c}\text { No } \\
\text { female } \\
\text { earner }\end{array}$ & $\begin{array}{c}\text { Single } \\
\text { female } \\
\text { earner }\end{array}$ & $\begin{array}{c}\text { Multiple } \\
\text { female } \\
\text { earners }\end{array}$ \\
\hline 2008 & & & \\
& Single male earner & 65.2 & 16.3 & 1.1 \\
& Multiple male earner & 12.9 & 3.6 & 0.8 \\
& Single male earner & 37.0 & 31.5 & 2.4 \\
& Multiple male earner & 15.6 & 12.0 & 1.5 \\
\hline Source: PRIME Survey Data $(2008,2013)$. & &
\end{tabular}

From Table III, it is pellucid that the dependency on single earning male members changed and in 2013 around $48 \%$ of households got income support from the female which was around $22 \%$ in 2008, a dramatic shift indeed. This shift suggests an overall improvement of the economy. But who moves fast? Particularly, does credit and non-credit support contribute to creating the earning options?

Table IV shows that in 2008 out of 4 households, about three households were dependent on single male earning members and around $16 \%$ had multiple male earning members whereas in 2013 the dependency on single-earner declined and the multiple male earning members increased.

Individuals are either wage-employed or self-employed. Some individuals are sometimes wage-employed and selfemployed. While the gender dimension of employment status is described above, it will be important to know the aggregate effect on total wage-employment days, total self-employment days, and in particular, total working days. These three statistics are presented in Fig. 1. A closer look at the figure shows that the number of working days, wage-employment, or self-employment or total, has increased from 2008 to 2013 for every group of people. These increments in working days reveal that the working opportunity has been created or expanded in the survey areas over the period. This improvement could either be due to the overall macroeconomic influence alongside the contribution of developmental activities in those areas by various organizations. In terms of working days, the households who receive credit and non-credit services of NGO-MFIs or other organizations had an almost similar number of working days, but the non-participants were relatively on the back foot.

TABLE IV: TREND OF NUMBER OF EARNERS BY STATUS OF PRIME PROGRAM

\begin{tabular}{|c|c|c|c|c|c|c|c|c|c|}
\hline Year & Number of earner & PCP & $\mathrm{PCO}$ & NPCO & NPCP & NP & Total & PCP vs. NP & PCO vs. NP \\
\hline \multirow{2}{*}{2008} & Single male & 77.23 & 75.79 & 74.78 & 73.21 & 67.12 & 74.02 & 10.11 & 8.67 \\
\hline & Multiple male & 18.21 & 14.82 & 17.63 & 13.4 & 12.16 & 15.82 & 6.05 & 2.66 \\
\hline 2013 & Single male & 65.68 & 65.27 & 65.33 & 61.56 & 58.1 & 63.83 & 7.58 & 7.17 \\
\hline \multirow{2}{*}{2008} & Single female & 27.66 & 27.77 & 21.39 & 23.44 & 25.83 & 24.9 & 1.83 & 1.94 \\
\hline & Multiple female & 2.36 & 2.28 & 2.02 & 2.88 & 1.95 & 2.18 & 0.41 & 0.33 \\
\hline \multirow{2}{*}{2013} & Single female & 46.91 & 48.71 & 44.95 & 50.97 & 44.2 & 46.32 & 2.71 & 4.51 \\
\hline & Multiple female & 5.81 & 4.34 & 4.71 & 5.57 & 3.5 & 4.62 & 2.31 & 0.84 \\
\hline
\end{tabular}

Source: PRIME Survey Data (2008, 2013). 
Comparing the PRIME households with the nonparticipant households, we find that PRIME households had 186 wage-employment days while non-participant households had 185, almost similar number of wageemployment days, but the number of self-employment days among the PRIME households was higher than the nonparticipant. The difference could be due to some PRIME households getting various services before 2008 and benefits could be accrued to the households.

Although it is clear that the number of earning members and number of working days had increased among the households irrespective of the households' participation status, there was an uneven start of the journey and therefore, it will be very difficult to claim that the gain was due to the PRIME initiatives. To eliminate the gain due to the better start, an adjusted value had been generated in such a way that they were put on the same line of starting pointing. The figures show that PRIME and non-participant households had a dissimilar start, but the adjustment shows that even the nonparticipant would start on the same condition of PRIME households, they could have a lower number of earning members and lower number of working days.

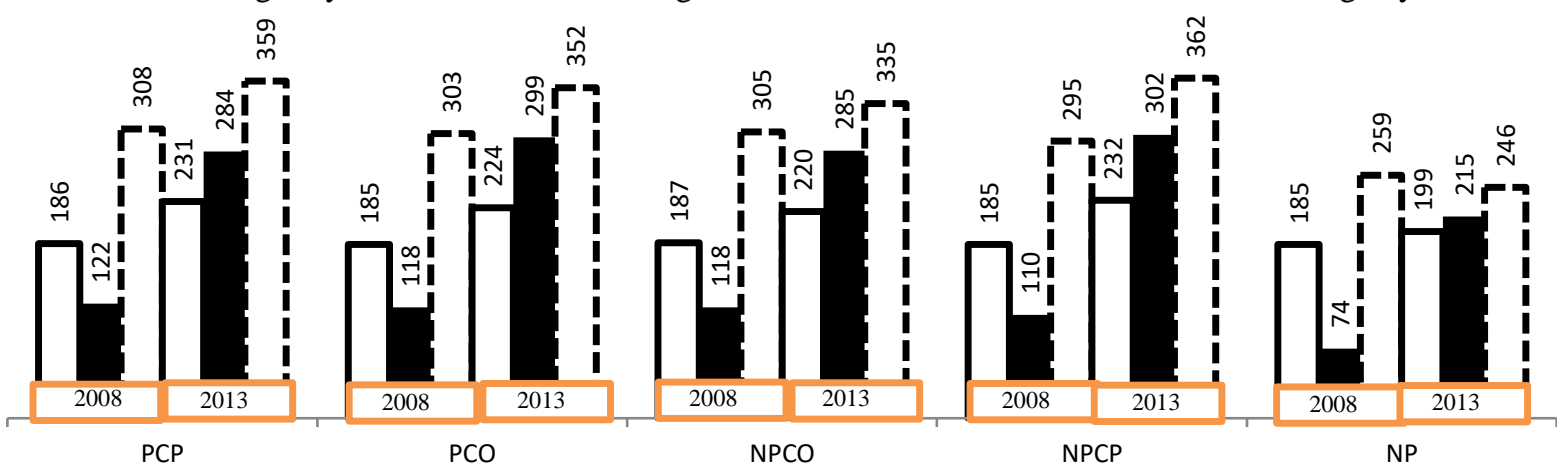

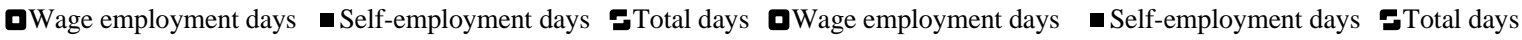

Fig. 1. Trend of working days (2008-2013) by program participation status. Source: PRIME Survey Data (2008, 2013).

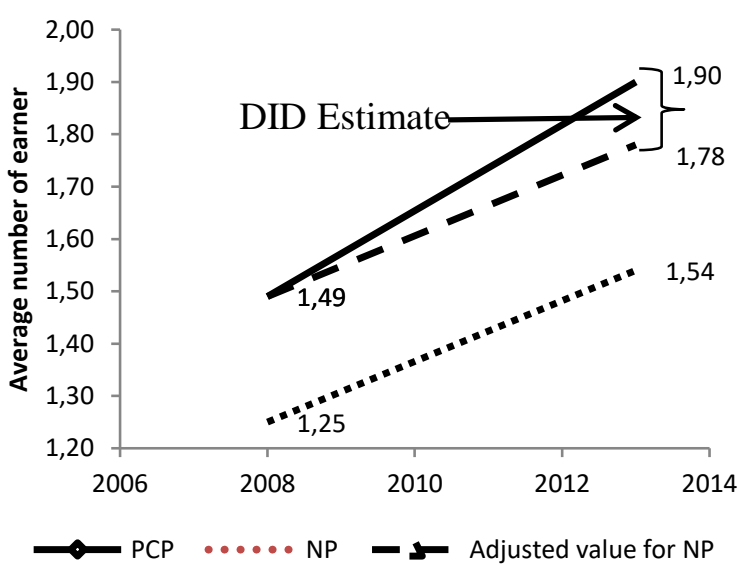

Fig. 2. The trend of average earning members among PRIME Credit Participant and Non-participant. Source: PRIME Survey Data (2008, 2013).

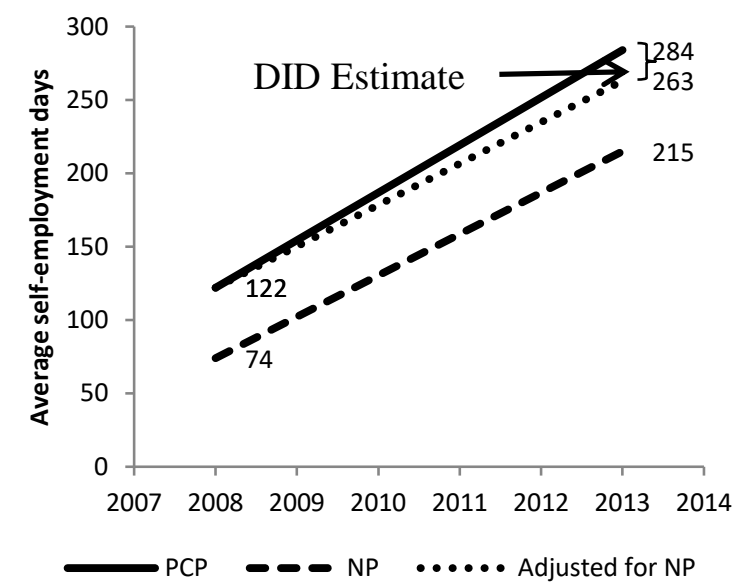

Fig. 4. The trend average self-employment days among PRIME credit participant and non-participant. Source: PRIME Survey Data (2008, 2013).

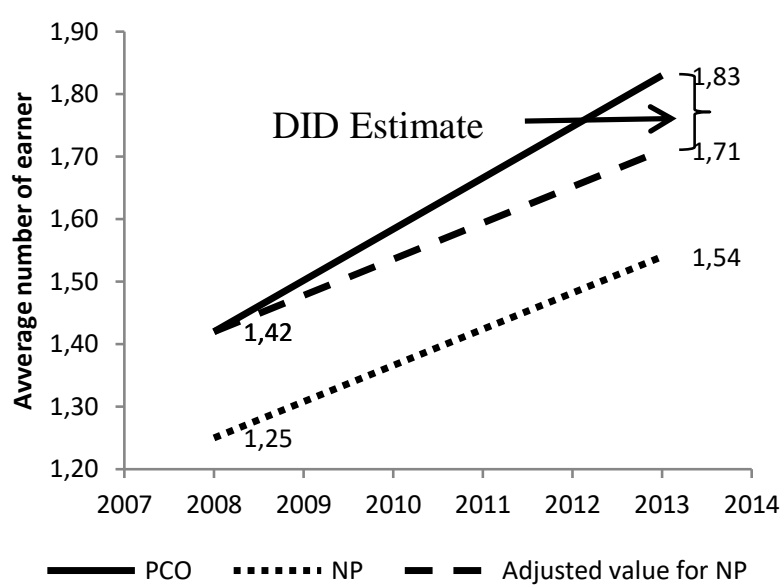

Fig. 3. The trend of earning members among PRIME other participant and non-participant. Source: PRIME Survey Data $(2008,2013)$.

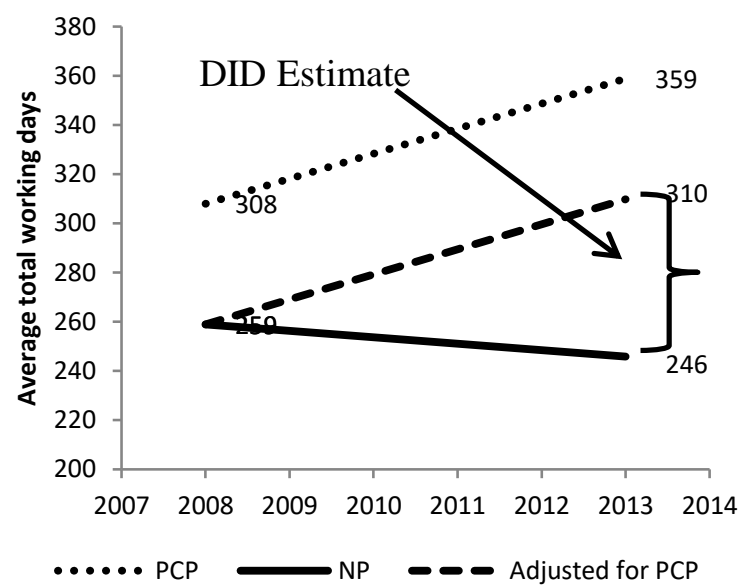

Fig. 5. The trend of total working days among PRIME other participant and non-participant. Source: PRIME Survey Data (2008, 2013). 
Although the descriptive analysis drew a clear and strong demarcation line between PRIME households and nonparticipant households in terms of the number of earning members and number of working days of the households, it was hardly tested by the statistical tools and techniques. We proposed four models to capture the effects of PRIME program on employment along with the significance of the effect. The summary results of the models are presented in the following table.

TABLE V: DID ESTIMATES OF WORKING DAYS (WAGE-EMPLOYMENT OR SELF-EMPLOYMENT DAYS OR BOTH)

\begin{tabular}{|c|c|c|c|c|}
\hline & $\begin{array}{c}\text { Model } 1 \\
\text { Coef/se }\end{array}$ & $\begin{array}{c}\text { Model } 2 \\
\text { coef/se }\end{array}$ & $\begin{array}{c}\text { Model } 3 \\
\text { coef/se }\end{array}$ & $\begin{array}{c}\text { Model } 4 \\
\text { coef/se }\end{array}$ \\
\hline $\begin{array}{l}\text { Self-employment } \\
\text { days of HH head } \\
\text { (Level) }\end{array}$ & $\begin{array}{l}19.924 \\
(15.505)\end{array}$ & $\begin{array}{l}22.813 \\
(15.453)\end{array}$ & $\begin{array}{l}24.814 \\
(15.32)\end{array}$ & $\begin{array}{l}28.359 * \\
(14.89)\end{array}$ \\
\hline $\begin{array}{l}\text { Self-employment } \\
\text { days HH head (Log) }\end{array}$ & $\begin{array}{c}0.29 * * * \\
(0.107)\end{array}$ & $\begin{array}{c}0.29 * * * \\
(0.107)\end{array}$ & $\begin{array}{l}0.30^{* * *} \\
(0.107)\end{array}$ & $\begin{array}{l}0.30 * * * \\
(0.106)\end{array}$ \\
\hline $\begin{array}{l}\text { Self-employment } \\
\text { days of household } \\
\text { (Level) }\end{array}$ & $\begin{array}{l}42.8 * * * \\
(12.708)\end{array}$ & $\begin{array}{l}42.9 * * * \\
(12.612)\end{array}$ & $\begin{array}{l}38.7 * * * \\
(12.539)\end{array}$ & $\begin{array}{l}40.5 * * * \\
(12.496)\end{array}$ \\
\hline $\begin{array}{l}\text { Self-employment } \\
\text { days household (Log) }\end{array}$ & $\begin{array}{c}0.30^{* * *} \\
(0.108)\end{array}$ & $\begin{array}{l}0.30 * * * \\
(0.108)\end{array}$ & $\begin{array}{c}0.31^{* * *} \\
(0.108)\end{array}$ & $\begin{array}{l}0.30 * * * \\
(0.107)\end{array}$ \\
\hline $\begin{array}{l}\text { Male self- } \\
\text { employment days } \\
\text { (Level) }\end{array}$ & $\begin{array}{l}41.3^{* * *} \\
(15.703)\end{array}$ & $\begin{array}{l}41.2 * * * \\
(15.692)\end{array}$ & $\begin{array}{l}40.7 * * * \\
(15.479)\end{array}$ & $\begin{array}{l}35.8 * * \\
(15.465)\end{array}$ \\
\hline $\begin{array}{l}\text { Male self- } \\
\text { employment days } \\
\text { (Log) }\end{array}$ & $\begin{array}{c}0.341 * * * \\
(0.109)\end{array}$ & $\begin{array}{l}0.34 * * * \\
(0.109)\end{array}$ & $\begin{array}{l}0.34 * * * \\
(0.108)\end{array}$ & $\begin{array}{l}0.30 * * * \\
(0.108)\end{array}$ \\
\hline $\begin{array}{l}\text { Female self- } \\
\text { employment days } \\
\text { (Level) }\end{array}$ & $\begin{array}{l}25.506 \\
(36.957)\end{array}$ & $\begin{array}{l}25.122 \\
(36.893)\end{array}$ & $\begin{array}{l}45.845 \\
(36.534)\end{array}$ & $\begin{array}{l}69.04 * * \\
(33.273)\end{array}$ \\
\hline $\begin{array}{l}\text { Female self- } \\
\text { employment days } \\
\text { (Log) }\end{array}$ & $\begin{array}{l}0.287 \\
(0.231)\end{array}$ & $\begin{array}{l}0.291 \\
(0.229)\end{array}$ & $\begin{array}{l}0.386^{*} \\
(0.228)\end{array}$ & $\begin{array}{l}0.517 * * \\
(0.211)\end{array}$ \\
\hline $\begin{array}{l}\text { Total wage working } \\
\text { days (Level) }\end{array}$ & $\begin{array}{l}30.9^{* * *} \\
(10.380)\end{array}$ & $\begin{array}{l}31.5^{* * *} \\
(10.311)\end{array}$ & $\begin{array}{l}34.1 * * * \\
(10.159)\end{array}$ & $\begin{array}{l}32.9 * * * \\
(10.167)\end{array}$ \\
\hline $\begin{array}{l}\text { Total wage working } \\
\text { days (Log) }\end{array}$ & $\begin{array}{c}0.127 * * * \\
(0.049)\end{array}$ & $\begin{array}{l}0.13^{* * * *} \\
(0.049)\end{array}$ & $\begin{array}{l}0.14^{* * * *} \\
(0.048)\end{array}$ & $\begin{array}{l}0.14 * * * \\
(0.048)\end{array}$ \\
\hline $\begin{array}{l}\text { Total working days } \\
\text { (Level) }\end{array}$ & $\begin{array}{l}64.1 * * * \\
(14.469)\end{array}$ & $\begin{array}{l}64.1 * * * \\
(14.456)\end{array}$ & $\begin{array}{l}62.2^{* * *} \\
(13.894)\end{array}$ & $\begin{array}{l}64.8 * * * \\
(13.541)\end{array}$ \\
\hline $\begin{array}{l}\text { Total working days } \\
\text { (Log) }\end{array}$ & $\begin{array}{l}0.2^{* * * *} \\
(0.044)\end{array}$ & $\begin{array}{l}0.2 * * * \\
(0.044)\end{array}$ & $\begin{array}{l}0.2 * * * \\
(0.043)\end{array}$ & $\begin{array}{l}0.2 * * * \\
(0.043)\end{array}$ \\
\hline
\end{tabular}

Note: $* * * \mathrm{p}<0.01, * * \mathrm{p}<0.05, * \mathrm{p}<0.1$; the figures in parentheses show the standard error (SE). The first model is a simple DID model (model without covariates), model 2 includes log of landholding as an additional variable, model 3 includes household characteristics (household size, access to electricity, and migrant member in the household), and model 4 is an extended version of model 3 which includes some area dummies. Source: Authors (2021).

The simple model, model 1, shows that PRIME has a positive impact on self-employment creation, households spending additional time on self-employment activities, but the relationship is not statistically significant. The first extended model, model 2, shows a similar result but the impact level increases from 20 days to 23 days. The impact of PRIME on self-employment in the second extended model is estimated at 25 days but not significant. The full-extension model, model 4, shows that PRIME has significantly contributed to increasing self-employment days among the program participant households. The impact of the program on self-employment is more pronounced in the log-lin specification of the models. The models show that within five years, the self-employment days increased by around 30\%, an average annual increment of about $6 \%$. The full extended model shows that the incremental self-employment days are influenced positively by the size of landholding, household size, age of household head, and years of schooling of the household head. The result shows that a $10 \%$ increase in landholding increases the self-employment days by around 2 days holding the effects of other variables constant, an additional household member increases the self-employment by around 21 days other things remain the same, and an additional year of schooling increases the self-employment by around 3.2 days ceteris paribus. The households having migrant members have lower self-employment days compared to their counterfactual other things remaining the same (Table VI).

TABLE VI: DID ESTIMATES OF SELF-EMPLOYMENT DAYS OF THE

\begin{tabular}{|c|c|c|c|c|}
\hline \multicolumn{5}{|c|}{ HOUSEHOLD (LEVEL) } \\
\hline & Model 1 & Model 2 & Model 3 & Model 4 \\
\hline & Coef/se & coef/se & coef/se & coef/se \\
\hline \multirow[t]{2}{*}{ Year dummy, 2013} & $27.2 * * *$ & $27.9 * * *$ & $33.0 * * *$ & $34.6^{* * *}$ \\
\hline & $(8.643)$ & $(8.577)$ & $(8.567)$ & $(8.605)$ \\
\hline \multirow{2}{*}{$\begin{array}{c}\text { Dummy of PRIME } \\
\text { Credit Participant }\end{array}$} & $48.1 * * *$ & $38.8 * * *$ & $25.4^{* *}$ & $25.5^{* *}$ \\
\hline & $(10.212)$ & $(10.137)$ & $(9.990)$ & $(9.941)$ \\
\hline \multirow{2}{*}{$\begin{array}{c}\text { Difference-in- } \\
\text { Difference Estimate }\end{array}$} & $42.8 * * *$ & $42.9 * * *$ & $38.7 * * *$ & $40.5 * * *$ \\
\hline & $(12.708)$ & $(12.612)$ & (12.539) & (12.496) \\
\hline \multirow[t]{2}{*}{ Log of landholding } & & $23.9 * * *$ & $18.3^{* * *}$ & $17.8 * * *$ \\
\hline & & $(2.651)$ & $(2.636)$ & $(2.621)$ \\
\hline \multirow[t]{2}{*}{ Household Size } & & & $21.2^{* * *}$ & $21.0 * * *$ \\
\hline & & & $(2.026)$ & $(2.006)$ \\
\hline \multirow{3}{*}{$\begin{array}{c}\text { The household has } \\
\text { an electricity } \\
\text { connection }\end{array}$} & & & & \\
\hline & & & $21.7^{* * *}$ & 14.1 \\
\hline & & & $(8.916)$ & $(8.812)$ \\
\hline \multirow[t]{2}{*}{$\begin{array}{l}\text { Household has } \\
\text { migrant member }\end{array}$} & & & $-49.4 * * *$ & $-57.5^{* * *}$ \\
\hline & & & (7.113) & (7.035) \\
\hline \multirow[t]{2}{*}{$\begin{array}{c}\text { Household head age } \\
\text { (year) }\end{array}$} & & & & $0.5 * *$ \\
\hline & & & & $(0.241)$ \\
\hline \multirow[t]{2}{*}{$\begin{array}{l}\text { Household head } \\
\text { education (Year) }\end{array}$} & & & & $3.2 * * *$ \\
\hline & & & & (1.232) \\
\hline \multirow{2}{*}{$\begin{array}{c}\text { District Fixed } \\
\text { Effect } \\
\text { Constant }\end{array}$} & No & No & No & Yes \\
\hline & $\begin{array}{c}72.1 * * * \\
(7.007)\end{array}$ & $\begin{array}{c}42.5 * * * \\
(7.665)\end{array}$ & $\begin{array}{c}-17.5^{*} \\
(10.167)\end{array}$ & $\begin{array}{l}-77.8^{* * * *} \\
(16.867)\end{array}$ \\
\hline
\end{tabular}

Note: $* * * \mathrm{p}<0.01, * * \mathrm{p}<0.05,{ }^{*} \mathrm{p}<0.1$; the figures in parentheses show the standard error (SE). The first model is a simple DID model (model without covariates), model 2 includes $\log$ of landholding as an additional variable, model 3 includes household characteristics (household size, access to electricity, and migrant member in the household), and model 4 is an extended version of model 3 which includes some area dummies. Source: Authors (2021).

The results of the impact of PRIME on self-employment creation are lucid and are statistically significant. These results are empirical evidences of the impressive positive impact of credit programs on employment creation. But whose self-employment we are talking about? To answer the question, we have estimated the effect of PRIME on male self-employment days and female self-employment days separately. The results show that there is a significant positive impact of PRIME on creating self-employment for men and 
women. The results show that holding other things remaining the same, PRIME has positively contributed to creating selfemployment opportunities among the female with an annual incremental rate of $10.2 \%$ which is around $6.2 \%$ among men.

The results also show that PRIME has increased the wageemployment opportunities among participants compared to the non-participant households. The full extended model shows that the PRIME participant households have around 33 extra wage-employment days compared to the nonparticipant households holding the effect of other variables constant. The log-lin model shows that the wage-employment days have increased by around $5.7 \%$ annually due to the PRIME initiatives. The individual household level analysis, the aggregate self-employment level analysis, the disaggregated self-employment analysis by gender, the wageemployment level analysis, and the aggregate household level employment analysis show that PRIME has significantly contributed to creating employment days within the program areas (Table V).

\section{SUMMARY AND CONCLUSION}

With the successful implementation of the microcredit program in Bangladesh, a conclusion was drawn that poor people can borrow, repay, and save. The question then arose "does microcredit improve the well-being of the borrowing households?" Studies were plethora which examined the question considering various dimensions of well-being. Most of the studies drew the concrete conclusion that microcredit significantly contributed to enhancing the welfare of the borrowing households. The dissonant voices are no less. The empirical evidence was questioned methodologically but the founding studies reiterated their findings and stick to the findings that microcredit does contribute to enhancing the well-being of the borrowing households. But one question remains, how? Surely it was assumed that the improved wellbeing is due to higher income and higher employment opportunities.

The descriptive analysis showed that in 2008 about $75 \%$ of households were dependent on single male earning members and $16 \%$ had multiple male earning members whereas in 2013 the dependency on single-earner declined and the multiple male earning members increased. The number of working days, wage-employment or self-employment or total, has increased from 2008 to 2013 for every group of people. These increments in working days reveal that the working opportunity has been created or expanded in the survey areas over the period. This improvement could either be due to the overall macroeconomic influence alongside the contribution of developmental activities in those areas by various organizations. In terms of working days, the households who receive credit and non-credit services of NGO-MFIs or other organizations had an almost similar number of working days, but the non-participants were relatively on the back foot. The women started to contribute to the household earnings. We also found that the borrowing ultra-poor households had gained around $21.1 \%$ extra employment days due to the participation opportunities within 2008-2013, with an annual rate of $4.2 \%$. The extra earning days included wage-employment days and selfemployment days and the result showed that the wage- employment days increased by $2.6 \%$ annually and the selfemployment days increased by $6.6 \%$ annually holding the effects of other explanatory variables constant.

Following Banerjee and Newman (1993) we have assessed the effect of credit and non-credit components of the designed microcredit program. We used working days: wageemployment days and self-employment days as a proxy of the nature of employment under the presumption that with constant wage or return to self-employment, the income of the household can be estimated. Two types of models were estimated to understand the impact of credit on employment creation: (i) simple difference-in-difference (DID) model model without covariates, and (ii) the difference-indifference model with a set of covariates. The simple model showed that PRIME has a positive impact on selfemployment creation for the household head, the household head spending additional time on self-employment activities, but the relationship is not statistically significant. The first extended model showed a similar result, but the impact level increases from 20 days to 23 days. The DID estimate of selfemployment days of households head in $2^{\text {nd }}$ extended model was 25 days which became 28 days in the full model. However, the log specification of the self-employment days of the household head showed that the DID estimates are statistically significant in all four models. The results for selfemployment working days of male working members of the households also showed a significant improvement due to the program participation decision. The results are also positive for female working members of the households, but a significant change is found in the full model. One interesting observation is the incremental self-employment days among female workers are higher than the incremental selfemployment days among male workers of the households. The results are highly significant both at the level and log specification of the working days.

The results of the impact of credit programs on selfemployment creation are lucid and are statistically significant. These results are empirical evidence of the impressive positive impact of credit programs on employment creation. The results show that there is a significant positive impact of PRIME on creating selfemployment for both male and female workers of the households. The results show that holding other things remaining the same, the credit program has positively contributed to creating self-employment opportunities among women than men. The individual household level analysis, the aggregate self-employment level analysis, the disaggregated self-employment analysis by gender, the wageemployment level analysis, and the aggregate household level employment analysis show that the credit program has positively and significantly contributed to creating employment days among the treatment households compared to the control households.

\section{ACKNOWLEDGMENT}

We are very much grateful to Prof. M.A. Baqui Khalily, former Professor, Department of Finance, University of Dhaka, for his insightful comments in preparing the paper. We are also acknowledging the people who worked in evaluating the PRIME program of PKSF. 


\section{REFERENCES}

Aidis, R. (2003). Entrepreneurship and economic transition.

Alnaa, S. E. (2017). Microcredit to Rural Women, Intra-household Power Play and Employment Creation in Northern Ghana. Journal of Interdisciplinary Economics, 29(2), 197-213.

Armendáriz, B., \& Morduch, J. (2010). The economics of microfinance. MIT press.

Assembly, U. G. (1948). Universal declaration of human rights. UN General Assembly, 302(2), 14-25.

Atiase, V. Y., Wang, Y., \& Mahmood, S. (2019). FNGOs and financial inclusion: Investigating the impact of microcredit on employment growth in Ghana. The International Journal of Entrepreneurship and Innovation, 20(2), 90-106.

Av, L. (2013). The structure of the model of self-employment factors in the country with transition economy: Lithuanian case. Transformations in Business \& Economics, 12(2), 29.

Banerjee, A. V., \& Newman, A. F. (1993). Occupational choice and the process of development. Journal of political economy, 101(2), 274298.

Brixiova, Z. (2013). Modeling productive entrepreneurship in developing countries. Small business economics, 41(1), 183-194.

Chodorow-Reich, G. (2014). The employment effects of credit market disruptions: Firm-level evidence from the 2008-9 financial crisis. The Quarterly Journal of Economics, 129(1), 1-59.

Emran, M. S., Morshed, A. K. M., \& Stiglitz, J. E. (2007). Microfinance and missing markets. Joseph E., Microfinance and Missing Markets (March 2007).

Goetz, A. M., \& Gupta, R. S. (1996). Who takes the credit? Gender, power, and control over loan use in rural credit programs in Bangladesh. World development, 24(1), 45-63.

Halder, S. R. (2003). 4. Poverty Outreach and BRAC's Microfinance Interventions.

Hossain, M. (1984). Credit for the rural poor; the experience of grameen [rural] bank in Bangladesh.

Hossain, M. (1988). Credit for alleviation of rural poverty: The Grameen Bank in Bangladesh (Vol. 65). Intl Food Policy Res Inst.

Habiba, N., \& Awan, Z. (2020). Mediating Role of Social Capital and Firm Value Creation in Relationship Among Microcredit, Networking and MSME's Performance in Pakistan. Global Economic Review, 1, 234 244.

Hulme, D., \& Moore, K. (2008). Assisting the poorest in bangladesh: Learning from BRAC's 'targeting the ultra-poor'programme. In Social protection for the poor and poorest (pp. 194-210). Palgrave Macmillan, London.

Khandker, S. (2001, February). Does micro-finance really benefit the poor? Evidence from Bangladesh. In Asia and Pacific Forum on Poverty: Reforming Policies and Institutions for Poverty Reduction (Vol. 14).

Khandker, S. R. (1996). Role of targeted credit in rural non-farm growth. The Bangladesh Development Studies, 181-193.

Korpysa, J. (2011). Factors determining decision about setting up a firm-the survey results from Poland.Transformations in Business \& Economics, 10(2).

Kritikos, A. S., \& Vigenina, D. (2005). Key factors of joint-liability loan contracts: an empirical analysis. Kyklos, 58(2), 213-238.

McKernan, S. M. (2002). The impact of microcredit programs on selfemployment profits: Do noncredit program aspects matter? Review of economics and statistics, 84(1), 93-115.

Mondragon, J. (2018). Household credit and employment in the Great Recession. Kilts Center for Marketing at Chicago Booth-Nielsen Dataset Paper Series, 1-025.

Moyi, E. D. (2013). Credit and employment growth among small enterprises in Kenya.

Pagano, M., \& Pica, G. (2012). Finance and employment. Economic Policy, 27(69), 5-55.

Pitt, M. M. (2000). The Effect of Non-agricultural Self-employment Credit on Contractual Relations and Employment in Agriculture: The Case of Microcredit Programmes in Bangladesh. The Bangladesh Development Studies, 15-48.

Rees, H., \& Shah, A. (1986). An empirical analysis of self-employment in the UK. Journal of applied econometrics, 1(1), 95-108.

Rushidan, I. R., Pitt, M., \& Khandker, S. R. (1996). Role of Targeted Credit Programs in Promoting Employment and Productivity of the Poor in Bangladesh. published in 'Credit Programs for the Poor: Household and Intra-household Impacts and Program Sustainability, 2.

Sahu, T. N., Agarwala, V., \& Maity, S. (2021). Effectiveness of microcredit in employment generation and livelihood transformation of tribal women entrepreneurs: evidence from PMMY.Journal of Small Business \& Entrepreneurship, 1-22.
Shehu, N., Mohammed, N. S., \& Ahmed, K. (2021). Impact of Microcredit Scheme on Entrepreneurial Development in North-Western Nigeria. International Journal of Intellectual Discourse, 4(1), 2-20.

Tria, D., Harun, M. B., \& Alam, M. M. (2020, November). Evaluating the Role of Microcredit Program for Youth Employment Generation in Algeria. In 2020 Second International Sustainability and Resilience Conference: Technology and Innovation in Building Designs (51154) (pp. 1-5). IEEE.

Wagner, J., \& Sternberg, R. (2004). Start-up activities, individual characteristics, and the regional milieu: Lessons for entrepreneurship support policies from German micro data. The annals of regional science, 38(2), 219-240.

Webster, L., Riopelle, R., \& Chidzero, A. M. (1996). World Bank lending for small enterprises, 1989-1993 (Vol. 311). World Bank Publications.

Yunus, M. (1987). Credit for self-employment: A fundamental human right. Grameen Bank.

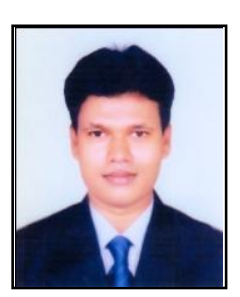

Md. Abdul Khaleque is an Assistant Professor at the Department of Development Studies, University of Dhaka. He has completed his Honors and Master's degree in Economics at the University of Dhaka, Bangladesh. He has completed his Ph.D. in Development Studies with a particular focus on water security with funding support from the School of Geography and the Environment, The University of Oxford under the project REACH. Earlier, he was Senior Research Associate at the Institute of Microfinance (InM) up to July 2013. He was associated with several important research projects of InM - PRIME (Programme Initiatives for Monga Eradication), Access to Financial Services; and Assessing risks, resilience, and adaptation strategies in the Chittagong Hill Tracts. He has a core team member of various researches for CARE Bangladesh, World Vision, UNICEF, and UNDP. His research interest includes enterprise development, poverty, water security, food security, climate change, regulation, microfinance, growth, finance and so on.

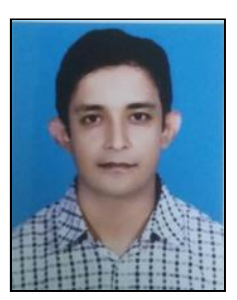

Mehadi Hasan is working as Manager in Research Division at Palli Karma-Sahayak Foundation (PKSF). He has completed his Honors degree in Economics from Shah Jalal University of Science \& Technology, Sylhet, Bangladesh, and Master's in Economics from North South University, Dhaka, Bangladesh. Currently, he is doing his Ph.D. from Bangladesh University of Professionals, Dhaka, Bangladesh with a particular focus on a community-based approach to climate change adaptation. Earlier, he was Senior Research Associate at the Institute for Inclusive Finance \& Development, Dhaka, Bangladesh up to October 2017. Major areas of his research include inclusive finance, microenterprise development, financial sector development, climate change, impact evaluation, etc.

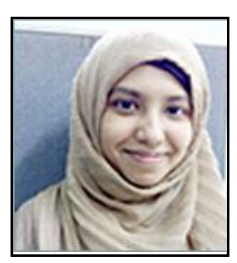

Farah Muneer is a researcher and policy analyst serving the development sector for about 10 years. She is currently working at UNDP as national consultant. She holds a Master's degree in Development Economics and Policy from the University of Manchester, United Kingdom. Her research works include various development issues, like, Microenterprise Development, Climate Change Issues and Resilience, Financial Inclusion, Women Empowerment, Multidimensional Poverty Analysis and Rural Finance. She has strong knowledge and experience in conducting and coordinating policy dialogues, developing tools for impact assessment and result based framework (RBF), supervising primary research, and conducting statistical analysis. She has published papers in different national and international journals. 